\title{
Properties of Accounting Income in Indonesia: Net Income and Total Comprehensive Income
}

\author{
Dwi Fitri Puspa, Listiana Srimulatsih, Zaitul
}

\begin{abstract}
Introduction- This study aims to investigate the quality of net income and total comprehensive earnings from four properties or characteristics. The characteristics in question are persistence, variability, predictability and value relevance. The samples of the research are manufacturing companies listed in Indonesian Stock Exchange in 2012. By employing sampling technique based on the criteria, 24 companies were selected as samples with period of data collection from 2012 to 2014. There are six hypotheses tested by using regression technique. The results of the research show some findings, namely that net income is more persistent than total comprehensive income, there is no significant difference in the variability between total comprehensive income and net income, net income has the ability to predict cash flow and net income for the upcoming year is better than the total comprehensive income and the relevance of net income is different from the total comprehensive income both by applying price and return model. IFRS convergence financial accounting standards require companies that have public accountability in Indonesia to present a comprehensive income statement that includes the presentation of net income, other comprehensive income and total comprehensive income. The results of the research on the characteristics of net income and total comprehensiveness benefit for various parties such as investors, financial analysts and creditors concerned with the quality of profit that is characterized from 4 perspectives mentioned before. For the financial accounting standards setter, results of this study provide information about the quality of comprehensive earnings.
\end{abstract}

Index Terms: Net Income, Total Comprehensive Income, Persistence, Variability, Predictive Ability, Value Relevance.

\section{INTRODUCTION}

The development of accounting standards has started since 1973. In 1973, for the first time, Indonesia had accounting standards which were named as the Indonesian Accounting Principles (IAPs). In late 1994, the Indonesian Institute of Accountants (the IIA), launched a new set of financial accounting standards, known as Financial Accounting Standards (FASs) to replace the old IAPs. They were based largely on International Accounting Standards (IASs). Since 2012, the local standards named Financial Accounting Standards applied in Indonesia are based on those IFRSs. The aim of improvement of Indonesian's

Revised Manuscript Received on September 22, 2019.

Dwi Fitri Puspa, Bung Hatta University, Indonesia, dwifp2012@yahoo.co.id

Listiana Srimulatsih, Bung Hatta University, Indonesia

Zaitul, Bung Hatta University, Indonesia. accounting standards is to enhance the quality of financial reporting practices.

Financial statements are useful source of information for various parties as the basis for economic decision-making. Under financial accounting standards based on IFRS that are effective from January 1, 2012 in Indonesia, companies with public accountability are required to present comprehensive income statements. The report consists of net income, other comprehensive income and total comprehensive income. The traditional income statement illustrates earnings based on the concept of narrow realization while comprehensive income statement describes profit with wider coverage. In the traditional income statement, revenue will be recognized if the cash has been realized or other assets that will eventually be realized into cash. In contrast, comprehensive income recognizes revenue even for unrealized transactions. As a consequence, comprehensive income will present less stable profit in- formation compared to net income.

This research investigates the properties of net income and total comprehensive income by using the sample of manufactures companies in Indonesia. Referring to research (1), this study will test four properties of net income and total comprehensive income as a basis for assessing the quality of earnings namely persistence, variability, predictability and value relevance (2). The properties of the comprehensive income have been studied previously by some researcher (1, $3-7)$. Research on the properties of net income and total comprehensive income is needed in Indonesia for various reasons; firstly, the Financial Accounting Standards Board (FASB) under the Indonesian Institute of Accountants (IIA) since 2008 has a commitment to support the implementation of financial accounting standards that refer to IFRSs (international financial reporting standards). This IFRS convergence financial accounting standard was enforced since 2012 (https: // www.iasplus.com.). With the enactment of this standard, the company is required to present the financial statements in accordance with the provisions contained in the standard. Secondly, the presentation of total comprehensive income in the income statement was first applied in Indonesia on or since January 1, 2009; thirdly, there are very few studies that analyze all of these four properties.

In addition to the above, research on properties of accounting income in the form of net income and total comprehensive income is very valuable 
This because shareholders interested in the quality of accounting earnings, such as investors, financial analysts, and creditors, will be able to identify whether quality net income or total comprehensive income that has a higher quality. For financial analysts, investors, financial analysts, creditors use earnings information to assess companies. Consequently, the results of this study will provide evidence of the properties of net income and total comprehensive income so that financial analysts will be more focused on net income or comprehensive income when assessing firms.

\section{LITERATURE REVIEW}

\section{A. Persistence of Net Income and Total Comprehensive Income.}

According to Dechow et al. (8), earnings are said to have better quality if they are more persistent and less volatile. Earnings are used to assess the company's financial performance. The accrual basis system is used to generate earnings. On an accrual basis, the matching principle is used to generate earnings. Total comprehensive income in it includes net income and other comprehensive income. Other comprehensive income includes the components of Changes in the revaluation surplus, actuarial gains and losses on defined benefit plans, profit and losses arising from translation of foreign financial statements, profit and losses from the financial assets re-measurement categorized as available for sale, and effective portion from the gain and loss o on hedging instruments in a cash flow. Since comprehensive income incorporates unrealized gain and losses, the volatility of markets and uncontrolled markets will make the items of gain and loss transitory. For this reason, it can be concluded that comprehensive income is more volatile than net income (9). If current earnings are now likely to keep persistence in the future, then earnings are considered to be more useful. Previous research investigated earnings persistence by splitting earnings on recurring items and non-recurring items.

Elliot and Hanna (10) discovered that investors place less weight on special items than earnings before special items. Investors put more weight on persistent measures as desirable since those

measures are recurring (11). Kabir et al. (1) reinforced these findings that documented that coefficient variables of net income and total comprehensive income are significant at less than 1 percent. Both results show that net income is more persistent than total comprehensive income. Therefore, the first hypothesis is:

H1a: Net Income is persistence

H1b: Total comprehensive income is not persistence

H1c: Net Income is more persistent than Total Comprehensive Income.

\section{B. The Variability of Net Income and Total Comprehensive Income}

Theorists adopted two different view points concerning the purpose of income statement (12). One favors the idea that income statement should enable prediction of future income numbers. This viewpoint assumes that income follows some trend, and that income statement should help in receiving that trend. Therefore, non-recurring items should not be reflected in the income statement. These items increase the variability of the income number, and therefore these non-recurring item obscure the view on the (true) trend. This view favors dirty surplus accounting. The use of fair value accounting in income measurement increases the volatility in financial accounting information. Research done by Barth et al. (9) documented that fair value-based earnings are more volatile than historical cost-based earnings. Further, the results of Hodder et al. (13) documented that the volatility of full value income is three times higher than comprehensive income. and five times higher than net income. Total comprehensive income incorporated more value changes than does net income, based on the evidence, net income is likely to be less volatile than TCI (1). Thus, the second hypothesis is:

H2: The cross-sectional variation of net income is less than that of total comprehensive income.

\section{Predictive Ability of Net Income and Total Comprehensive Income}

Earnings is a summary of company performance measures prepared using the accrual basis accounting and used by various users. The principle of revenue recognition and matching principle is used as a guideline to generate earnings. The recognition principle reveals that revenue is recognized if the company has performed all or part of the services and cash receipts can be recognized. The matching principle states that cash expenditures are directly related to revenue will be expensed to the period of revenue recognition. This income statement also presented based on accruals from the application of the revenue recognition and matching principles. Further total comprehensive income includes other comprehensive income that report further accruals that reflect transitory revaluations of assets and liabilities (1). Application of accruals in recognizing the revenue and the use of matching principles in preparing the net income make the net income better predict future cash flows and net income than do accruals arising from transitory valuation changes in total comprehensive income $(2,14,15)$. Chen et al (16) found that operating income and net income explain security returns better than comprehensive income. Based on this the hypothesis is:

$\mathbf{H}_{3 \mathbf{a}}$ : Net income predicts one-year-ahead cash flow from operating

$\mathbf{H}_{3 \mathbf{b}}$ : Total comprehensive income predicts one-year-ahead cash flow from operating

$\mathbf{H}_{3 \mathbf{c}}$ : Net income predicts one-year-ahead cash flow from operating better than total comprehensive income.

$\mathbf{H}_{4 \mathbf{a}}$ : Net income predicts one-year-ahead net income

$\mathbf{H}_{\mathbf{4 b}}$ : Total comprehensive income predicts one-year-ahead net income 
$\mathbf{H}_{4 \mathrm{c}}$ : Net income predicts one-year-ahead net income better than total comprehensive income.

\section{Value Relevance of Net income and Total Comprehensive Income}

A key role of financial statements is to summarize business trans- actions and other events. It is assumed that financial statements enable investors in determining firm value and because of that investors demand value-relevant information from financial state- ments (17). The value relevance of financial statement infor-mation is measured by its ability to capture or summarize infor- mation, regardless of source, that affects share values (18). This is consistent with a measurement perspective on accounting. That is, accounting is viewed as an instrument for measurement (19). Values relevance testing is a form of testing to operationalize the relevant criteria and reliability that exist in the conceptual framework compiled by the Financial Accounting Standards Board(14). Both criteria serve as the basis for selecting among the existing accounting alternatives. Accounting information is stated to have value relevance if it is able to make a difference to the users' decision. In the research, the value relevance in accounting information is relevant if the accounting information reflects the information relevant to the investor and is used in assessing the company as well as measured reliably, it can be reflected in the stock price. Relevant information will make a difference to users' decisions. Prior studies use both return and price model report that earnings are value relevant $(16,18,20-24)$.

Earnings persistence is believed to be an important factor contributing to variations in value relevance (25-27). If current earnings tend to persist in the future then earnings are expressed as useful information (16). The information content of the earnings component is increased by the component of persistent earnings $(11,28)$. As mentioned earlier total comprehensive in- come includes more transitory items than that of net income. If net income is more persistent than total comprehensive income investors may view, net income more value relevant than total comprehensive income (1).

The results in the research by Goncharov and Hodgson (29) found that the values relevance of net income is higher than the total comprehensive income. On the contrary, other research results give different results. For example, Dhaliwal et al (1999) examined whether net income or total comprehensive income has a better performance measurement model. The results of his re- search conclude that the relevance of comprehensive income value is not higher than the relevance of net income value. Similarly, the results of the research by Cahan et al. (2000) showed that the incremental value of total comprehensive income did not increase after the issuance of financial reporting standard 2 relevance of comprehensive income value is not better than net income. Contrary to the results of the above research. It is evident that the relevance of the comprehensive value of income is higher than net income either by using price model in 1994. Meanwhile, Devalle \& Magarini (30) found that the

or return model. Based on this explantion, the hypotheses are

H5a: Net income is value relevant by using return and price model $\mathrm{H} 5 \mathrm{~b}$ : Total comprehensive income is value relevant by using return and price model

H5c: The value relevance of net income differs from total comprehensive income by using return and price model

\section{METHODOLOGY}

This section provides an outline of methodology employed for examining the properties of net income and total comprehensive income. The first part of this section explains sample and data collection. Part two presents valuation models to examine the properties of accounting income including the persistence, variability, predictive ability, and value relevance.

\section{A. Data}

The sample selection starts with manufactures companies listed in Indonesia Stock exchange in 2012. A total of 136 manufacture companies are listed in Indonesia stock exchange in 2012. The sample period was 2012-2014. The same companies were maintained throughout the period of study. The criteria used to select the sample are (i) the companies that have other comprehensive income items (i.e. Net income and total comprehensive incomes are not the same); (ii) financial statements are not presented in foreign currency; (iii) net profit reporting firms and (iv) the same companies listed throughout the period of study. Based on this sample selection, the numbers of companies that fulfill the criteria is 24 companies. Thus, the final observation during 2012-2014 is 72 companies. Table 1. describes the sample selection.

Table 1: Sample selection

\section{Sample Selection}

Sample period was 2012-2014 136

Start with manufacture firms listed in Indonesia

Stock Exchange in 2012

Less: the firms have Net Income $=$ Total

Comprehensive Income (2012-2104)

Less: net loss reporting firms during 2012-2104

Less: foreign currency reporting firms during 2012-2014

Less: delisting firms

Sample that fulfill the criteria.

Final observation during 2012-2014

72

The accounting information data are obtained from company annual report in Indonesia stock exchange.

\section{B. Valuation Model}

As mentioned in previous section, there are four model to measure the properties of net income and total comprehensive income, namely the persistence, variability, predictive ability, and value relevance. 
Persistence. These two models persist in literature to measure the earnings persistence (1). These models are used in this study as follows:

$$
\begin{aligned}
& N I_{t+1}=\alpha+\beta N I_{t}+\varepsilon_{t} \\
& T C I_{t+1}=\alpha+\beta T C I_{t}+\varepsilon_{t} \\
& \text { where: } \\
& \text { NI : Net Income; } \\
& \text { TCI: Total Comprehensive Income }
\end{aligned}
$$

To follow the most studies in the persistence literature both NI and TCI are deflated by the weighted average number of shares to mitigate the effects of heteroskedasity (31). According to Dechow and Schrand, (2) the closer $\beta$ is to 1 , the more persistent the net income and total comprehensive income.

Variability. To examine the variability of these two types of ac- counting income this study uses standard deviation. Further, standard deviation of net income are compared with that of total comprehensive income (9).

Predictive ability. This study uses the predictive ability approach to assess the ability of two income metric, namely NI and TCI, in forecasting one-year-ahead cash flows from operating activities and net income. These models provide which income metric - NI and TCI - can predict one-year-ahead CFO and net income better. According to Dechow (31) adjusted $\mathrm{R}^{2}$ is used to measure the predictive ability of net income and total comprehensive income. Models with higher adjusted R2 indicate that the accounting in- come has better predictability. Model (3) and (4) employ to measure the ability of net income and total comprehensive income to predict one-year-ahead cash flows from operating net income. On the other hand, model (5) and (6) are employed to examine the ability of net income and total comprehensive income to predict one-year-ahead net income. All variables in these models are deflated by the weighted average number of shares.

These models are as follows:

$$
\begin{aligned}
& C F O_{t+1}=\alpha+\beta N I_{t}+\varepsilon_{t} \\
& C F O_{t+1}=\alpha+\beta T C I_{t}+\varepsilon_{t} \\
& N I_{t+1}=\alpha+\beta N I_{t}+\varepsilon_{t} \\
& N I_{t+1}=\alpha+\beta T C I_{t}+\varepsilon_{t}
\end{aligned}
$$

where:

NI $=$ Net Income

$\mathrm{qTCI}=$ Total Comprehensive Income

$\mathrm{CFO}=$ Cash Flows From Operating Activities

Value Relevance. Most studies use two types of valuation models to measure the value relevance. They are return model and price model. A return model explains the relationship between stock returns and accounting earnings or the relationship between stock returns and cash flows. A price model describes the relationship between market values and earnings and book values of equity. Return model only allow assessing value relevance of accounting earnings, cash flows, whereas price models based on Ohlson (12) show how a firm's market value is related to both book values of equity and accounting earnings. Since these two components of accounting information play different roles in security pricing, the use of Ohlson model will expands the scope of value-relevance research. Based on the price model developed by (12), the value of a firm's equity can be expressed as a function of its earning and book value. Price (2) model based on (12) has become popular in accounting research to examine the relevance of financial data by regressing stock prices on earnings plus book values such as $(16,18,24)$. Kothari and Zimmerman (32) describe that both returns and price models have theoretical econometric and theoretical problems. Therefore, researchers are advised to use both models together to measure the value relevance. On this basis, this study uses both models. These models are presented in model 7,8,9 and 10 .

$$
\begin{aligned}
R_{t} & =\alpha+\beta\left(N I C_{t-} P_{t-1}\right)++\varepsilon_{t} \\
R_{t} & =\alpha+\beta\left(\text { TCIC }_{t-} \boldsymbol{P}_{t-1}\right)+\varepsilon_{t} \\
\boldsymbol{P}_{t} & =\alpha+\beta_{1} B V_{t}+\beta_{2} N I C_{t}+\varepsilon_{t} \\
\boldsymbol{P}_{t} & =\alpha+\beta_{1} B V_{t}+\beta_{2} \text { TCIC } C_{t}+\varepsilon_{t}
\end{aligned}
$$

Where:

$\mathrm{R}_{\mathrm{t}}=$ stock returns over the fiscal year minus returns on the Indonesia market portfolio,

$\mathrm{NIC}_{\mathrm{t}} \mathrm{Pt}_{-}$1 = net income to common per share deflated by begin- ning-of-year price,

$\mathrm{TCIC}_{\mathrm{t} \_\mathrm{Pt}} \mathrm{1}=$ total comprehensive income to common per share deflated by beginning-of-year stock price.

\section{RESULTS AND FINDINGS.}

This section presents the result on properties test of net income and total comprehensive income.

\section{A. Descriptive Statistics.}

Table 2: Descriptive Statistics

\begin{tabular}{lllll}
\hline Variables & Means & Maximum & Minimum & Std. Div \\
\hline NI & 332,64 & 2468,3 & 2,4253 & 509,98 \\
NI+1 & 309,02 & 2468,3 & 2,4253 & 526,67 \\
TCI & 370,89 & 2465,9 & 1,7643 & 529,75 \\
TCI+1 & 361,27 & 2465,9 & 1,7640 & 536,39 \\
BV & 1704,1 & 6383,5 & 3,17 & 1629,3 \\
Rt & 0,101 & 0,971 & -9.594 & 1,308 \\
CFO & 313,82 & 2612,8 & $-964,21$ & 603,31 \\
\hline
\end{tabular}

Descriptive statistics on variables are presented in Table 2. Mean net income is 332.64 whilst mean Net Income one year-ahead is 309,02 . Standard deviation for net income is 509,98 and 526,67 for Net income one year-ahead. Mean of total comprehensive income and total comprehensive income one year-ahead is 370,89 and 361,27 , respectively. Standard deviation for total comprehensive income is 529,75 and 536,39 for total comprehensive income one year-ahead. Mean book value is 1704,1 whilst mean return is 0,101 . Standard deviation for book value is 1629,3 and 1,308 for return. Descriptive statistics of cash flow operation one year-ahead shows mean of 313,82 and standard deviation is 603,31 . Because of these models employ simple regression then the issue of

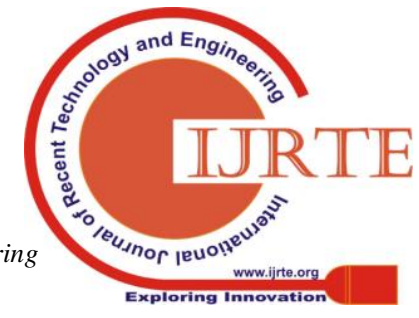


multi collinearity does not arise in models (1) - (8). Model (9) and (10) do not report multi collinearity problem.

\section{B. Results on the Properties of Net Income and Total Comprehensive Income.}

Table 3 presents the results of persistence, variability, predictive ability and value relevance related to net income and total comprehensive income.

Table 3: Results on properties of net income and total comprehensive income

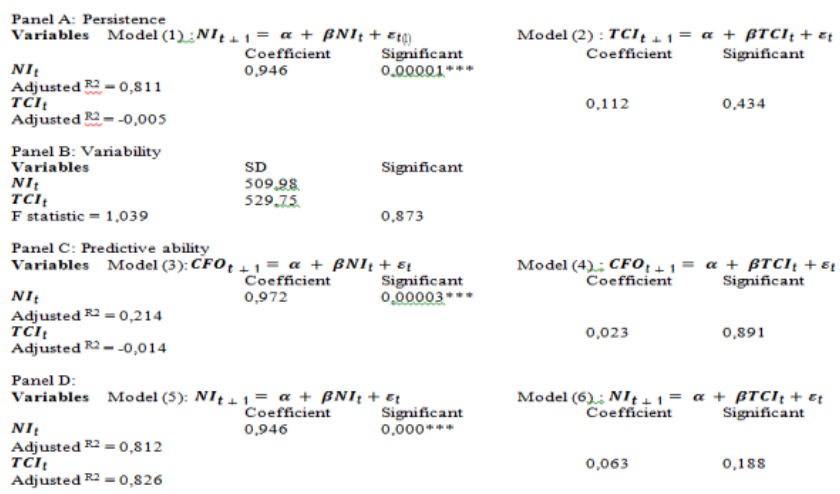

Notes: Statistically significant at: $* 10, * * 5$, and $* * * 1$ percent, NIt $=$ current year net income per year; TCIt $=$ current year total comprehensive income per share; $\mathrm{TCICt}=$ current year total comprehensive income to common per share

Panel A shows the results of persistence testing regression. Model

1 explains the relationship between net income and net income in the upcoming year while model 2 illustrates the relationship be- tween total comprehensive income and total comprehensive in- come for the next year. The results show that net income is significant at level $1 \%$ whereas total comprehensive income is not significant. The coefficients of net income and total comprehensive income are 0,946 and 0,112 respectively. The adjusted $\mathrm{R}^{2}$ is 0,811 and $-0,005$ for model (1) and (2), respectively. Thus, these results document that net income is persistence while total comprehensive income is not persistence. These results support $\mathrm{H}_{1}$ a but do not support $\mathrm{H} 1 \mathrm{~b}$. Overall these findings show that net income is more persistence than total comprehensive income. This evidence sup- ports $\mathrm{H}_{1} \mathrm{c}$. The empirical result is consistent with the findings re- ported in previous research done by Barton et al.(3) and (1). Barth et al. (14) found that net income is more persistent than total comprehensive income. Kabir et al. (1) documented that coefficient variables of net income and total comprehensive income are 0.755 and 0.656 , respectively. Both coefficients are significant at less than 1 percent.

Panel B shows the results of variability test related to net income and total comprehensive income variables. Standard deviation of both net income and total comprehensive income are 509,98 and 529,75 respectively. These results report that the variability of total comprehensive income is higher than net income variability. However, the variability difference is not significant at the $5 \%$ level. Thus, the $\mathrm{H}_{2}$ is not supported. These results are consistent with (1), reporting that there is no variability difference between net income and total comprehensive income.

Panel $\mathrm{C}$ summarizes the regression results on the ability of net income and total comprehensive income to predict one-year- ahead cash flow from operating activities. The coefficient of net income variable is 0,972 which is statistically significant at $1 \%$. The coefficient of total comprehensive net income variable is 0,023 which is statistically not significant at $10 \%$. The adjusted $\mathrm{R}^{2}$ for both model are 0,214 and $-0,014$, respectively. These results show that net income predicts one-year-ahead cash flow from operating activities but total comprehensive income do not. Thus, $\mathrm{H}_{3} \mathrm{a}$ is supported whereas $\mathrm{H}_{3} \mathrm{~b}$ is not supported. Based on these findings, net income has better ability to predict than total comprehensive income. These results support $\mathrm{H}_{3} \mathrm{c}$ stating that net income predicts one-year-ahead cash flow from operating better than total comprehensive income. These findings are in line with the empirical evidence documented in Barth et al. 2001a, b; Goncharov and Hodgson, 2008 but they found that the coefficients of net income and total comprehensive income are negative and significant. Further, contrary to results of (1) that found that net in- come does not predict one-year ahead cash flow from operating activities better than total comprehensive income.

Panel D in Table 3 presents the regression results on the ability of net income and total comprehensive income to predict one-year-ahead net income. As stated in this panel, model (5) is significant at $1 \%$ while model (6) is not significant at $10 \%$. The coefficients and the adjusted $\mathrm{R}_{2}$ are 0,946, 0,812 for model (5) respectively and 0,063 and 0,826 for model (6) respectively. These results provide evidence that the net income predicts one-year-ahead net income in turn, total comprehensive income does not. Overall, these results show that $\mathrm{H} 4 \mathrm{a}$ is supported and $\mathrm{H} 4 \mathrm{~b}$ is not supported. These findings are consistent with those reported in (1) who found that net income and total comprehensive income predict a year ahead. Overall, the results of both models show that net income predicts net income a year ahead better than the ability to predict total comprehensive income. This result is not in line with what is found by (1) which shows that net income predicts net income next year is not better than the total comprehensive income prediction ability.

Table 4: Results on value relevance

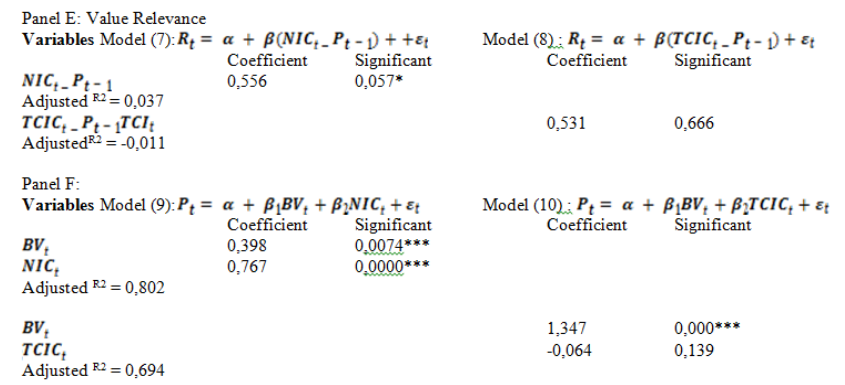

Notes: Statistically significant at : $* 10, * * 5$, and $* * * 1$ percent, NIt = current year net income per year; TCIt $=$ current year total comprehensive income per share; TCIC $_{t}=$ current year total comprehensive income to 
common per share; NICt_Pt-1 = common year net income to common per share deflated by beginning of year price; TCICt_Pt-1= current year total comprehensive income to common per share deflated by beginning of year price $; \mathrm{BVt}=$ book value per share.

Panel $\mathrm{E}$ in tables 4 provides the regression result to examine the value relevance test. Both models describe the relationship be- tween stock returns and net income and total comprehensive. Model (7) shows that net income is statistically significant at $10 \%$. Coefficient of net income is 0,556. Further, model (8) reports total comprehensive income is not statistically significant at $10 \%$ and the coefficient is 0,053 . The adjusted $\mathrm{R}^{2}$ for both models are 0,037 and $-0,011$, respectively These results indicate that net in- come is value relevant but total comprehensive income is not value relevant. Thus, $\mathrm{H}_{5} \mathrm{a}$ is supported and $\mathrm{H} 5 \mathrm{~b}$ is not supported. From both models, it can be concluded that value relevance of net in- come is higher than that of total comprehensive.

Panel $\mathrm{F}$ reports results on the value relevance of net income and total comprehensive income by using price model. The coefficient is 0.767 when net income is the independent variable and $-0,064$ when total comprehensive income is the independent variable. Model (9) is statistically significant at less than $1 \%$ but model (10) is not statistically significant. The adjusted $\mathrm{R}^{2}$ for both models are 0,802 and 0,694 , respectively. These findings show that $\mathrm{H} 5 \mathrm{a}$ is supported and $\mathrm{H} 5 \mathrm{~b}$ is not supported. These results are consistent with the prior studies done by Kabir et al, (1) that documented net income and total comprehensive income are value relevant. From both models it is found that the relevance of net income value is higher than the total comprehensive value. Thus, the $\mathrm{H}_{6 \mathrm{c}}$ is sup- ported. These findings are not consistent with those reported in Kabir et al. (1). Kabir et al. (1) found that there is no difference the value relevance of net income compared to that of total comprehensive income. The results of this study also differ from who found the relevance of the higher comprehensive income value compared to the net income in both the return and the price model. These findings show the net income coefficient is higher than that of total comprehensive income. This is because total comprehensive income reports more transitory items in calculating the in- come than that of net income (32). Investors place less value on nonrecurring items than earnings before nonrecurring items. Results in Panel $\mathrm{E}$ and $\mathrm{F}$ reinforce the result from Barton et al. $(1,3)$. $(1,3)$ found that total comprehensive income is less value relevant.

\section{CONCLUSION}

This research is intended to examine the properties of accounting incomes which are divided into net income and total comprehensive income in Indonesia. This research is motivated by the implementation of Financial Accounting tandards in accordance with the IFRS since 2012. There are four properties to be tested: persistence, variability, predictive ability and value relevance. The results show that (i) net income is persistent while total comprehensive

income is not (ii) there is no difference of variability between net income and total comprehensive income (iii) net income can predict cash flow from operation for one year ahead while total comprehensive income is not (iv) the ability to predict net income better of comprehensive income (v) net income has value relevance by using price model and return model. In contrast, total comprehensive income has no value relevance in both models. Ultimately, the value relevance of net income is greater than the total comprehensive income.

This study provides evidence to investors, standard setter and securities analysts on the properties of net income and total comprehensive income after listed companies in Indonesia required to present total comprehensive income in financial statement. Overall, these results show which metric, net income or total comprehensive measures firm performance. Analysts use companies fundamentals to value a firm and other users use earnings in different contractual settings. The study is not without its limitation. This study uses the small size of the sample. Thus, the generalizability of these findings is limited.

\section{REFERENCES}

[1] Humayun Kabir M, Laswad F. Properties of net income and total comprehensive income: New Zealand evidence. Accounting Research Journal. 2011;24(3):268-89.

[2] Dechow P, Ge W, Schrand C. Understanding earnings quality: A review of the proxies, their determinants and their consequences $\$$. Journal of Accounting and Economics. 2010;50(2-3):344-401.

[3] Barton J, Hansen TB, Pownall G. Which Performance Measures Do Investors Around the World Value the Most-and Why? The Accounting Review. 2010;85(3):753-89.

[4] [Chambers D, Linsmeier ÆTJ, Shakespeare ÆC. An evaluation of SFAS No . 130 comprehensive income disclosures. Review of Accounting Studies. 2007;12(130):557-93.

[5] Courtenay SM. Value Relevance of Mandated Comprehensive Income Disclosure Value Relevance of Mandated Comprehensive Income Disclosures. 2000(June 2016).

[6] Dhaliwal D, Subramanyam KR, Trezevant R. Is comprehensive income superior to net income as a measure of firm performance ? Journal of Accounting and Economics. 1999;26:43-67.

[7] Hanlon JFO, Pope PF. THE VALUE-RELEVANCE OF UK DIRTY SURPLUS ACCOUNTING FLOWS. British Accounting Review. 1999;31:459-82.

[8] Dechow P, Ge W, Schrand C. Understanding earnings quality: A review of the proxies, their determinants and their consequences. Journal of accounting and economics. 2010;50(2):344-401.

[9] Barth ME, Landsman WR, Wahlen JM. Fair value accounting: Effects on banks earnings volatility, regulatory capital, and value of contractual cash flows. Journal of Banking \& Finance. 1995;19:577-605.

[10] Elliott JA, Hanna JD. Repeated accounting write-offs and the information content of earnings. Journal of accounting research. 1996:135-55.

[11] Penman SH, Zhang X-j. the Quality of Earnings, and Stock Returns. The Accounting Review. 2002;77(2):237-64.

[12] Ohlson JA. On Transitory Earnings. Review of Accounting Studies. 1999;4:145-62.

[13] Hodder LD, Hopkins PE, Wahlen JM. Risk-relevance of fair-value income measures for commercial banks. The Accounting Review. 2006;81(2):337-75

[14] Barth ME, Beaver WH, Landsman WR. The relevance of the value relevance literature for financial accounting standard setting: Another view. Journal of Accounting and Economics. 2001;31(1-3):77-104.

[15] [Barth ME, Cram DP, Nelson KK. Accruals and the Prediction of Future Cash Flows in Hong Kong. The Accounting Review. 2001;76(April):27-58. 
[16] Chen CJP, Chen S, Su X. Is accounting information value-relevant in the emerging Chinese stock market? Journal of International Accounting Auditing \& Taxation. 2001;10:1-22.

[17] Nilsson H. Essays on the value relevance of financial statement information. 2003

[18] Francis J, Schipper K. Have Financial Statements Lost Their Relevance? Journal of Accounting Research Journal of Accounting Research. 1999;37(2):319-52.

[19] Marton J. Acconting and stock markets: A study of swedish accounting for international investors and analysts Vol. 35, No. 2, 2000. International Journal Of Accounting. 1998;35(2):302-3.

[20] Alford A, Jones J, Leftwich R, Zmijewski M. The Relative Informativeness of Accounting Disclosures in Different Countries. Journal of Accounting Research. 1993;31:183-223.

[21] Amir E, Harris TS, Venuti EK. A comparison of the value-relevance of U. S. versus Non-U. S. GAAP accounting measures using Form 20-F reconciliations. Journal of Accounting Research. 1993;31(1993):230-64.

[22] Amir E, Lev B. Value relevance of nonfinancial information: the wireless communications industry. Journal of Accounting \& Economics. 1996;22:3-30.

[23] Harris S, Coenenberg A, Diehl U, Edwards F, Kuhne E, Mueller G, et al. The Value Relevance of German Accounting Measures : An Empirical Analysis. Journal of Accounting Research. 1994;32(2):187-209.

[24] Lev B, Zarowin P. The boundaries of financial reporting and how to extend them. Journal of Accounting Research. 1999;37(2):353-.

[25] Kormendi R, Lipe R. Earnings Innovations , Earnings Persistence , and Stock Returns *. Journal of Business. 1987;60(3):323-45.

[26] Ramakrishnan RTS, Thomas JK. Journal of Accounting, Auditing \& Finance. Journal of Accounting, Auditing \& Finance. 1998;13:(301):1-37.

[27] Zarowin.P AA. and The Role of Earnings Levels in Annual Earnings-Returns Studies. Journal of Accounting Research. 1992;30(2 Autumn):286-96.

[28] Lipe R. The Information Contained in the Components of Earnings. Journal of Accounting Research. 1986;24:37-64.

[29] Goncharov I, Hodgson A. Comprehensive income in Europe: valuation, prediction and conservative issues. Annales Universitatis Apulensis Series Oeconomica. 2008;1(10).

[30] Devalle A, Onali E, Magarini R. Assessing the value relevance of accounting data after the introduction of IFRS in Europe. Journal of international financial management \& accounting. 2010;21(2):85-119.

[31] Dechow PM. Accounting earnings and cash flows as measures of firm performance: The role of accounting accruals. Journal of accounting and economics. 1994;18(1):3-42.

[32] Kothari SP, Zimmerman JL. Price and return models. Journal of Accounting \& Economics. 1995;20:155-92.

\section{AUTHORS PROFILE}

I am Dwi Fitri Puspa, I am from Bung Hatta University, Indonesia and my area of interest is accounting and finance.

I am Listiana Srimulatsih, I am associated with Bung Hatta University, Indonesia and my area of interest is accountancy.

My name is Zaitul, I am attached with Bung Hatta University, Indonesia my area of research is accounting and finance. 